\title{
Significant of Antimullerian Hormone [AMH] Test for Women Infertility
}

\author{
Battikhi MN* \\ Battikhi central Laboratory, Canada \\ Submission: December 20, 2016; Published: January 18, 2017 \\ *Corresponding author: Battikhi Mohammed Nizar, 1017-1645 De Maisonneuve O, Montreal H3H 2N3, QC Canada, \\ mailto: m_nizar11@hotmail.ca" m_nizar11@hotmail.ca
}

\section{Introduction}

Over the last decade, a large number of studies examining the multiple roles of AMH have been published [1]. AMH produced by granulosa cells [GC] of the ovary [2,3]; $\mathrm{AMH}$, also known as Mullerian-inhibiting substance, is a dimeric glycoprotein that belongs to the transforming growth factor $-\beta$ family $[4,5]$. It is virtually undetectable but increases gradually until puberty and remains relatively stable through the reproductive period [6,7]. It is widely accepted that the reduction of AMH levels in serum is the first indication for decline in the follicular reserve of the ovaries and can be measured in the blood at any time in the menstrual cycle due to its stability $[8,9]$. AMH is a marker for ovarian reserve and naturally lower in older women [ $>40$ year] and higher in women with Polycystic ovaries [PCO] and polycystic Ovary Syndrome [P OCS] $[10,11]$. It was reported that Follicle stimulating hormone [FSH), Estradiol [E2] levels and antral follicle count [AFC] have been used for evaluation of ovarian reserve to determine suitable treatment strategy for female infertility by age $[2,11]$, which becomes very essential in recent years.

Traditionally, age, follicle stimulating hormone [FSH), [E2] levels and antral follicle count $[\mathrm{AFC}]$ at have been used for evaluation of ovarian reserve the early follicular phase [2]. Levels of FSH and E2 were considered to be the determining biochemical markers for assessment of low ovarian reserve for many years [2] and FSH level was found above the norm only in cases when the ovary function is largely decreased [12] however, it is still the most commonly used test although its reliability is weak and also FSH association with significant inter- and intra-cycle variability is documented [13,14]. Opposing to FSH, AMH is considered to be more specific marker for ovarian response to gonadotrophins In comparison with other ovarian reserve assessment tests and is characterized by a number of advantages. AMH level is stable throughout the menstrual cycle and therefore can be measured at any day of the cycle $[14,15]$ and it is not affected by other hormonal variations, including the use of oral contraceptives [16].

Recent studies have shown that AMH can be a good predictor of ovarian reserve and the success rates of in vitro fertilization
[IVF] [17-19] however, both AMH and FSH are still used as ovarian reserve tests [20] although FSH showed several obstacles where patients have been reported to show discordant values for their ovarian reserve and cycle outcome [10,21-23], poor response to gonadotrophin stimulation on day 3 [23], lower chances of pregnancy [24] except at high threshold level of ovarian response. Adding to that FSH needs to be measured during early follicular phase [25-27]. In contrast AMH comparing to other ovarian reserve assessment tests is characterized by a number of advantages and can be tested on any day of the menstrual cycle [28-30], although variation in level of FSH between different blood samples for the same patient was reported during the same menstrual cycle especially in young patients $[31,32]$ never the less AMH can still show $80 \%$ sensitivity and $93 \%$ specificity in predicting poor ovarian response at random blood test [33].

AMH level showed correlation with number of oocytes retrieved and hence treatment can be individualized for optimal cycle [28-30]. The fact that AMH reported to show assays controversies [34], pregnancies even at undetectable levels [35] and intra-cycle variations level [32] raised question mark about the possible role of AMH in reproduction assessment. Although other studies showed that levels of FSH and E2 were used as biochemical markers for assessment of low ovarian reserve for many years, identification of AFC at later stage still considered more reliable marker in assessment of the ovarian reserve where, Follicle count can be determined easily using high resolution sonographic systems [26,36,37], although few reports showed that some difficulties were faced in obtaining AFC however, it had been recommended over basal FSH [38].

Thus, by some investigators AFC is considered as the first choice test and FSH and AMH are two different hormones that can be used to predict ovarian reserve at two different stages of follicular development [26,38] although FSH level had been reported to reflect antral and postantral follicular development while, AMH values represent post primordial prenatal follicular pool [21]. Despite the use of both FSH and AMH hormones in 
parallel to determine ovarian reserve, there is not much literature about the frequency of discordance and concordance between them and its clinical significance [21]. Therefore, future research still required to determining the frequency of concordance and discordance between AMH and FSH levels in female infertility patients and assessment of ovarian reserve to determine the strategy for treatment of female infertility. Recently, identification of AMH levels became important in assessment of ovarian reserve and identification of AMH level for assessment of ovarian reserve is a recent method to follow and the obtained data are divergent, implementation of further studies and obtaining more materials in this field are viewed as justified and reasonable.

The available test measures how much "anti-müllerian hormone" a woman produces in her ovarian follicles, is fast becoming the pre-eminent tool for fertility specialists in North America and Europe to determine the chances of their patients getting pregnant reported by Dr. Tom Hannam of the Hannam Fertility Centre in Toronto as reported by Cathy Gulli [39]. The objective of this editorial is to illustrate the significant of antiMullerian hormone $[\mathrm{AMH}]$ in respect to other fertility hormone such as follicle stimulating hormone $[\mathrm{FSH}]$ so that we the most reliable marker could be indicated and adequate strategy for the initial stages of infertility treatment could be laid out.

\section{References}

1. Karkanaki A, Vosnakis C, Panidis D (2011) The clinical significance of anti-Müllerian hormone evaluation in gynecological endocrinology. Hormones (Athens) 10(2): 95-103.

2. Barbakadze L, Kristesashvili J, Khonelidze N, Tsagareishvili G (2009) The Correlations of Anti-Mullerian Hormone, Follicle-Stimulating Hormone and Antral Follicle Count in DifferentAge Groups of Infertile Women. Int J Fertil Steril 91(6): 2616-2619.

3. Barrend WM, Uilenbroek JT, Kramer P, Hoogerbrugge JW, van Leeuwen EC, et al. (1995) "Anti-mullerian hormone amd antimullerian hormone type II receptor messenger ribonucleic acid expression inrat ovaries during postnatal development, the estrous cycle,ropin-induced follicle growth". Endocrinology 136(11): 4951-4962.

4. Van Rooij IA, Broekmans FJ, Scheffer GJ, Looman CW, Habbema JD, et al. (2005) Serum antimullerian hormone levels best reflect the reproductive decline with age in normal women with proven fertility: a longitudinal study. Fertil Steril 83(4): 979-987.

5. Fanchin R, Schonauer LM, Righini C, Frydman N, Frydman R, et al. (2003) Serum anti-Mullerian hormone dynamics during controlled ovarian hyperstimulation. Hum Reprod 18(2): 328-332.

6. Hin R, Schonauer LM, Righini C, Frydman N, Frydman R, Taieb J (2003) Serum anti-Mullerian hormone dynamics during controlled ovarian hyperstimulation. Hum Reprod 18(2): 328-332.

7. Hussain M, Cahill D, Akande V, Gordon U (2013) "Discrepancies between Antimullerian Hormone and Follicle Stimulating Hormone in Assisted Reproduction". Obstet Gynecol Int p. 6.

8. Van Rooij IA, Broekmans FJ, Scheffer GJ, Looman CW, Habbema JD, et al. (2005) "Serum antimullerian hormone levels best reflect the reproductive decline with age in normal women with proven fertility: a longitudinal study". Fertil Steril 83(4): 979-987.

9. Fanchin R., Schonäuer LM, Righini C, Frydman N, Frydman Ret al. (2003) "Serum anti-Mullerian hormone dynamics during controlled ovarian hyperstimulation". Human Reproduction 18(2): 328-332.
10. La Marca A, Volpe A (2006) "Anti-Müllerian hormone (AMH) in female reproduction: is measurement of circulating AMH a useful tool?". Clin Endocrinol (Oxf) 64(6): 603-610.

11. Durlinger AL, Gruijters MJ, Kramer P, Karels B, Kumar TR et al. (2001) "Anti-Müllerian hormone attenuates the effects of FSH on follicle development in the mouse ovary". Endocrinology 142(11): 4891-4899.

12. Gleicher N, Weghofer A, Barad DH (2010) "Discordances between follicle stimulating hormone (FSH) and anti-Müllerian hormone (AMH) in female infertility". Reprod Biol Endocrinol 8: 64.

13. Van Montfrans JM, Hoek A, van Hooff MH, de Koning CH, Tonch N, et al. (2000) "Predictive value of basal follicle-stimulating hormone concentrations in a general subfertility population". Fertil Steril 74(1): 97-103.

14. Baarends WM, Uilenbroek JT, Kramer P, Hoogerbrugge JW, van Leeuwen EC, et al. (1995) Anti-müllerian hormone and antimüllerian hormone type II receptor messenger ribonucleic acid expression in rat ovaries during postnatal development, the estrous cycle, and gonadotropininduced follicle growth. Endocrinology 136(11): 4951-4962.

15. Kelsey TW, Wright P, Nelson SM, Anderson RA, Wallace WH (2011) A validated model of serum anti-Müllerian hormone from conception to menopause. PLoS One 6(7): e22024.

16. Barad DH, Weghofer A, Gleicher N (2009) Comparing anti-Mullerian hormone (AMH) and follicle-stimulating hormone (FSH) as predictors of ovarian function. Fertil Steril 91(4 Suppl):1553-1555.

17. Lekamge DN, Barry M, Kolo M, Lane M, Gilchrist RB, et al. (2007) AntiMullerian hormone as a predictor of IVF outcome. Reprod Biomed Online 14(5): 602-610.

18. Jayaprakasan K, Deb S, Batcha M, Hopkisson J, Johnson I, Campbell $\mathrm{B}$, et al. "The cohort of antral follicles measuring 2-6 mm reflects the quantitative status of ovarian reserve as assessed by serum levels of anti-Mullerian hormone and response to controlled ovarian stimulation". Fertil Steril 94(5): 1775-1781.

19. Baarends WM, Uilenbroek JT, Kramer P, Hoogerbrugge JW, van Leeuwen EC, et al. (1995) "Anti-müllerian hormone and antimüllerian hormone type II receptor messenger ribonucleic acid expression inrat ovaries during postnatal development, the estrous cycle, and gonadotropininduced follicle growth". Endocrinology 136(11): 4951-4962.

20. Bancsi LF, Broekmans FJ, Eijkemans MJ, de Jong FH, Habbema JD, et al. (2002) "Predictors of poor ovarian response in in vitro fertilization: a prospective study comparing basal markers of ovarian reserve". Fertil Steril 77(2): 328-336.

21. Smeenk JM, Sweep FC, Zielhuis GA, Kremer JA, Thomas CM, et al. (2007) "Antimullerian hormone predicts ovarian responsiveness, but not embryo quality or pregnancy, after in vitro fertilizationor intracyoplasmic sperm injection". Fertil Steril 87(1): 223-226.

22. Leader B, Hegde A, Baca Q, Stone K, Lannon B, et al. (2012) "High frequency of discordance between anti-Müllerian hormone and follicle-stimulating hormone levels in serum from estradiol-confirmed days 2 to 4 of the menstrual cycle from 5,354 women in U.S. fertility centers". Fertil Steril 98(4): 1037-1042.

23. Molinaro T, Samra A (2011) "Patients with discordant AMH and FSH have a better prognosis in in-vitro fertilization than those with two abnormal markers of ovarian reserve". Fertility and Sterility 96(3): S199.

24. Cahill DJ, Prosser CJ, Wardle PG, Ford WLC, Hull MGR (1994) "Relative influence of serum follicle stimulating hormone, age and other factors on ovarian response to gonadotrophin stimulation". British Journal of Obstetrics and Gynaecology 101(11): 999-1002.

25. Esposito MA, C Coutifaris, KT Barnhart (2002) “A moderately elevated day 3 FSH concentration has limited predictive value, especially in younger women". Human Reproduction 17(1): 118-123. 
26. Broekmans FJ, Kwee J, Hendriks DJ, Mol BW, Lambalk CB (2006) "A systematic review of tests predicting ovarian reserve and IVF outcome". Hum Reprod Update 12(6): 685-718.

27. Wolff EF and Taylor HS. (2004) "Value of the day 3 follicle-stimulating hormone measurement”. Fertil Steril 81(6): 1486-1488.

28. Toner JP, Philput CB, Jones GS, Muasher SJ (1991) "Basal folliclestimulating hormone level is a better predictor of in vitro fertilization performance than age". Fertil Steril 55(4): 784-791.

29. La Marca A, Sighinolfi G, Radi D, Argento C, Baraldi E, et al. (2010) "Anti-Müllerian hormone (AMH) as a predictive marker in assisted reproductive technology (ART)". Hum Reprod Update 16(2): 113-130.

30. Anderson RA, Nelson SM, Wallace WH (2012) "Measuring antiMüllerian hormone for the assessment of ovarian reserve: when and for whom is, it indicated?"Maturitas 71(1): 28-33.

31. Yates AP, Rustamov O, Roberts SA, Lim HY, Pemberton PW, et al. (2011) "Anti-Müllerian hormone-tailored stimulation protocols improve outcomes whilst reducing adverse effects and costs of IVF". Hum Reprod 26(9): 2353-2362.

32. Wunder DM, Bersinger NA, Yared M, Kretschmer R, Birkhäuser MH (2008) "Statistically significant changes of anti-Müllerian hormone and inhibin levels during the physiologic menstrual cycle in reproductive age women". Fertil Steril 89(4): 927-933.
33. Overbeek A, Broekmans FJ, Hehenkamp WJ, Wijdeveld ME, van Disseldorp J, et al. (2012) "Intra-cycle fluctuations of anti-Müllerian hormone in normal women with a regular cycle: a re-analysis". Reprod Biomed Online 24(6): 664-669.

34. La Marca A, Giulini S, Tirelli A, Bertucci E, Marsella T, Xella S, et al. (2007) "Anti-Müllerian hormone measurement on any day of the menstrual cycle strongly predicts ovarian response in assisted reproductive technology". Human Reprod 22(3): 766-771.

35. Weghofer A, Dietrich W, Barad DH, Gleicher N (2011) "Live birth chances in women with extremely low-serum anti-Müllerian hormone levels". Hum Reprod 26(7): 1905-1909.

36. Nelson SM, Anderson RA, Broekmans FJ, Raine-Fenning N, Fleming R, La Marca A (2012) "Anti-Müllerian hormone: clairvoyance or crystal clear?" Hum Reprod 27(3): 631-636.

37. Broekmans FJ, Soules MR, Fauser BC (2009) "Ovarian aging: mechanisms and clinical consequences”. Endocr Rev 30(5): 465-493.

38. Tarlatzis BC, Zepiridis L, Grimbizis G, Bontis J (2003) “Clinical management of low ovarian response to stimulation for IVF: a systematic review". Hum Reprod Update 9(1): 61-76.

39. Cathy Gulli Maclean's National Post March 14, 2012

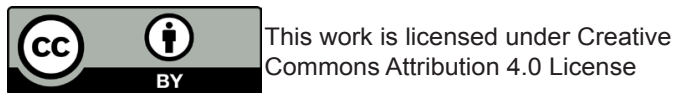

\begin{tabular}{l} 
Your next submission with Juniper Publishers \\
will reach you the below assets \\
- Quality Editorial service \\
- Swift Peer Review \\
- Reprints availability \\
- E-prints Service \\
- Manuscript Podcast for convenient understanding \\
- Global attainment for your research \\
- Manuscript accessibility in different formats \\
( Pdf, E-pub, Full Text, Audio) \\
- Unceasing customer service \\
Track the below URL for one-step submission \\
https://juniperpublishers.com/online-submission.php \\
\hline
\end{tabular}

